\title{
Temporal consistencies in two champion teams of European football? ¿Regularidades temporales en dos campeones del fútbol europeo?
}

\author{
Miguel PicAguilar \\ Universidad de La Laguna(España)
}

\begin{abstract}
The main objective of the work was to analyze the performance carried out by competitive football teams in their respective regular leagues during the 2015-16 season. All matches played by Leicester F.C. as a representative of the Premier League (n = 38) were considered, while Barcelona F.C. was the team representing La Liga $(\mathrm{n}=38)$. Intra and inter championship monitoring of these champion teams was carried out taking into account seven variables: team, location, quality, warnings, changes of players, goals, and final result. The data matrices were constructed and analyzed using variables temporal reference through the Theme data reduction technique (Magnusson, 2000). From the analysis of the specificity of soccer success in two of the best European championships, formulas that are difficult to detect through a superficial look were extracted. Paying attention to the records' context of appearance justifies a vision braided through a temporality thread. This work's findings can be used by sports managers in their longterm planning, while in the short and medium-term coaches can also take advantage of them. Optimizing high-level sports performance requires new analytical perspectives to understand how success arises in football.
\end{abstract}

Keyword. Temporality; football; T-patterns; Premier League; La Liga.

Resumen. El objetivo prioritario del trabajo era analizar el rendimiento protagonizado por equipos competitivos de fútbol en sus campeonatos respectivos de liga regular durante la temporada 2015-16. Se incluyeron todos los partidos del Leicester F.C. representante de la premier league (n=38) mientras que el equipo representante de La Liga fue el Barcelona F.C. (n=38). Se acometió un seguimiento intra e inter campeonato de los equipos campeones atendiendo a cinco variables: equipo, localización, calidad, amonestaciones, cambios de jugadores, goles y resultado final. Las matrices de datos fueron construidas y analizadas mediante el empleo de la referencia temporal de las variables, empleando para ello la técnica de reducción de datos Theme (Magnusson, 2000). Del análisis de especificidad del éxito futbolístico en dos de los mejores campeonatos del panorama europeo se extrajeron fórmulas difícilmente detectables mediante una mirada superficial. Atender al contexto de aparición de los registros justifica una visión trenzada mediante un hilo de temporalidad. Los hallazgos pueden ser aprovechados a largo plazo por directores deportivos en sus planificaciones, mientras que a corto y medio plazo también los entrenadores pueden verse ayudados. Optimizar el rendimiento deportivo de alto nivel precisa de nuevas perspectivas de análisis mediante las que conocer a qué responde el éxito en fútbol.

Palabras clave. Temporalidad; fútbol; T-patterns; Premier League; La Liga.

\section{Introduction}

Studying sports performance requires the identification of variables with a real impact on the result. Football is a cooperation-opposition sport (Parlebas, 2001), spatially invasive (Fernández-Rio, \& MéndezGiménez), in which 22 players grouped in two teams of 11 players dispute the possession of the ball in order to introduce it in the rival goal. Scoring more goals than the opponent to win a match hides implies great decision complexity due to the emergence of unexpected effects, approachable from a systemic adaptation and collective intelligence perspective. The players' ability to synchronize their actions against the opposing team, taking motor decisions at a dizzying pace, can help to determine on which facets rests sports performance in football.

In male basketball several performance indicators were used, such as the type of defense, transitions, defensive changes, aids, inside passes, opposition to pitches and points received, distinguishing winning and non-winning teams, as well as their effectiveness (Álvarez, Ortega, Gómez, \& Salado, 2009), while female basketball contrasted the importance of playing as a local linked to a higher number of rebounds, two-point pitches, number of assists and steals. In contrast, winning team outnumbered in three and free throws non-winning teams (Gómez, Lorenzo, Ortega, \& Olmedilla, 2007). Following a proposal that studied performance in baseball (Courneya, \& Cheiadurai, 1991)it was proposed the analysis of performance in soccer with indicators associated with theresult and procedures followed by teams (Castellano, \& Casamichana, 2016), such as playing time, offense of finalization, game model, physical indicator and space use, which were in turn shattered into more precise indicators. Also, the fundamental skill execution, scoring and final results of the game were applied to study attack actions in soccer (Cavalera, Diana, Elia, Jonsson, Zurloni, \& Anguera, 2015). On the other hand, the physical requirements of soccer players in La Liga (Castellano, BlancoVillaseñor, \& Álvarez, 2011) and the Premier League(Bradley, Sheldon, Wooster, Olsen, Boanas, \& Krustrup, 2009) were also analyzed.

Fecha recepción: 16-06-17. Fecha de aceptación: 26-10-17

Miguel Pic Aguilar

pic.aguilar.90@ull.edu.es
Knowing the models of success offered by the different leagues of the continent could be useful to complete the interpretive circle around factor interaction models (Pollard, \& Pollard, 2005).

Examining the findings related to the advantage of playing at home (HA) from the present, in light of the previous advances (Pollard, 1986), confers on it a diachronic character due to the habilitation of the temporal perspective. In individual sports HA has been found in judo (Gayton, \& Langevin, 1992) or wrestling matches (Krumer, 2017) showing the positive influence of HA for both genders. It was also interesting to face opponents of lower quality to increase the probability of winning. In collective sports, the favorable effect of the local role was also contrasted (Jamieson, 2010). Cricket (Morley, \& Thomas, 2005), basketball (García, Saéz, Ibáñez, Parejo, \& Cañadas, 2009), volleyball (Marcelino, Mesquita, Palao, \& Sampaio, 2009), rugby (Gómez, Pollard, \& Luis-Pascual, 2011) or handball(Pollard, \& Gómez, 2012)are examples of similar effects.

The existence of HA in soccer was also contrasted, with values of HA around 62\%(Clarke, \& Norman, 1995) or 69\%(Corneya, \& Carron, 1992). HA studies in England reached values of 64\% (Pollard, 1986) and 62\% (Pollard, 2006). During 6 seasons of regular league 2006-2012 with HA of $61.12 \%$ in the Premier League (PL), while in La Liga $61.66 \%$ percentages were reached (Pollard, \& Gómez, 2014) although in a previous study reached values of $60.20 \%$ (Gómez, Pollard, \& LuisPascual, 2011). More molecular records showed different abilities to recover the ball depending on the outcome, space and location of the match (Gómez, Gómez-López, Lago, \& Sampaio, 2012).

Minor HA was found by examining the location of teams when switching to a new stadium as local (Pollard, 2002). In European twolegged tie competitions (Page, \& Page, 2007) HA was also found when being local during the second match of double-qualifying matches, specifically in the knockout round of eighth of the Copa del Rey (Pic, \& Castellano, 2017). However, these effects disappeared in subsequent qualifying rounds of the same championship, coinciding with previous studies (Pic, \& Castellano, 2016). An even greater proportion of teams were classified to play the last phase of the UEFA Champions League championship or Copa del Rey when playing as visitors, which directly refers to consider a possible HA reverse effect, as evidenced by studies in hockey (Wright, \& Voger, 1995) or golf (Wright, \& Jackson, 1991). 
The proximity of the public to the field of play was also consistent, being recorded the increase of warnings and expulsions on the visiting team in the Champions League and in La Liga (Buraimo, Simmons, \& Maciaszczyk, 2012). For this purpose, previously tried and tested procedures (Buraimo, Forrest \& Simmons, 2010) were used in the German championship and in the Premier League (Boyko, Boyko, \& Boyko, 2007), with similar results.

The quality of the teams (Gruic, Vuleta, \& Milanovic, 2006; LagoPeñas, \& Lago-Ballesteros, 2011) was consistent with waterpolo (Gómez, de la Serna, Lupo, \& Sampaio, 2016). The higher quality teams were more effective in handball when recovering balls, and when performing assists and counterattacks (Gómez, Lago-Peñas, Viaño, \& González-García, 2014). In soccer, the disappearance of effects on HA in double-match eliminations was supported by the inclusion of the quality of teams (Eugster, Gertheiss, \& Kaiser, 2010), when effects on quality were contrasted, and their interaction with location (Bray, Law, \& Foyle, 2003). Dominating possession of the ball rested on higher quality teams (Lago, 2009), distinguishing teams that used interceptions or tackles (Almeida, Ferreira, \& Volossovitch 2014). The superior teams showed more patterns of play regardless of the evolution of the score (Lago-Peñas, \& Dellal, 2010). Through different indicators, three levels of quality of soccer teams were justified through k-cluster analysis (Liu, Yi, Giménez, Gómez, \& Lago-Peñas, 2015).

There are few research contributions in soccer (Buraimo, Simmons, \& Maciaszczyk, 2012; Buraimo, Forrest, \& Simmons, 2010) that include time to tackle success. The inclusion of a temporal dimension (Cavalera et al., 2015) could offer an enriching vision of a successful outcome. A viable alternative is the approach of the data reduction technique (Magnusson, 2005), widely used from an observational methodology (Anguera, \& Hernández-Mendo, 2014; Anguera, \& Hernández-Mendo, 2016).

Through the technique of analysis Theme (2005), the identification of T-patterns was performed. That is, the selection of events occurring in a defined order and with a specific time interval, scarcely variable. Its applications to different sport disciplines such as soccer field effectiveness (Lapresa, Camerino, Cabedo, Anguera, Jonsson, \& Arana, 2015), boxing or swimming among others (Jonsson et al., 2010) have been firmly demonstrated in contexts of ecological practice (Balagué, Torrents, Hristovski, \& Kelso, 2017; Anguera, \& Hernández-Mendo, 2016). Unveiling the temporal structure in soccer (Borrie, Jonsson, \& Magnusson, 2002) brings a vision in syntony with the situational specificity (Gómez, Lago, \& Pollard, 2013; Caballero, García-Rubio, \& Ibáñez, 2017) of soccer to find out the game model of F.C. Barcelona (Camerino, Chaverri, Anguera, \& Jonsson, 2012). More T-patterns were found in the second parts than in the first ones in matches of the Italian League A (Cavalera et al., 2015). Recently (Amatria, Lapresa, Arana, Anguera, \& Jonsson, 2017) it was found that 7 and 8 year old players had difficulty making one-touch plays in soccer 7 and soccer 8 respectively, but it is concluded that both participation models were adequate for these ages. This comparative does not take into account the country or league, but the subject of investigation has been revealing how the game is played in different European leagues. While the Premier League is associated with a direct game model, a form of play based on possession of the ball was attributed to the Spanish League (Sarmento, Pereira, Matos, Campaniço, Anguera, \& Leitão, 2013). The Premier League is one of the most physically demanding ones (Dellal et al., 2011), with fewer passes than in the Italian A Series (Rampinini, Impellizzeri, Castagna, Coutts, \& Wisløff, 2009) and more long passes than in the Spanish league (Barnes, Archer, Hogg, Bush, \& Bradley, 2014). Therefore, the existence of evidences that prove the specificity in two of the league (Veroz, Yagüe, \& Tabernero, 2015) championships more competitive at the moment are the Premier League and La Liga. Therefore, there is evidence that proves specificity in different championships. For all of the above, the main objective of the study was to reveal the emergence of temporal and behavioral regularities, according to the concept of HA and quality of the teams in both championships.

\section{Method}

\section{Participants}

For the study 2 teams were selected, both of them regular league champions in their respective countries, specifically during the 201516 season. Leicester F.C was selected from the Premier League, in the English championship, while Barcelona F.C. represented La Liga. 76 football matches were selected, 38 of which corresponded to each of the study teams.

\section{Variables codification}

The variables used were 1) team; a) Leicester F.C. (1), (b) Barcelona F.C. (b) and c) team (x), opponent of the previous teams. Second, for criterion 2) location; was divided between a) home (h) when Barcelona F.C. or Leicester F.C., played at home, and b) away (a) when Barcelona F.C. or Leicester F.C. played outside their own stadium. On the other hand, 3) the quality of the rival teams, was operationalized through 4 levels of competition competence; a) corresponded to teams among the top 5 ranked, b) teams ranked 6 to 10 (mq), c) between 11-15 (mmq), d) the last 5 ranked (sq). 4) admonitions; a) yellow card (y), b) red card (r); changes made by the coaches were recorded using variable 5) a) replacements made (c); the goals scored by the teams constitute variable 6) which considers, a) goals scored (g) and b) penalty goals (gp). Finally, the variable 7) match score; a) when the team scores more goals than its rival and wins (w), b) tie (d), while c) lose (l).

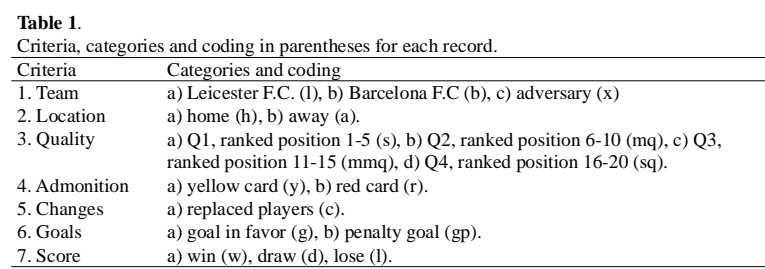

\section{Procedure}

Data were taken from the official pages of the spanish (www.laliga.es) and english (www.premierleague.com) leagues, and they were later checked with the national and international sections in BdFutbol (www.bdfutbol.com). Once the data relating to each champion team were available, the time of the records was unified according to the championship. Day one preceded day two and so on until the last day, so that if a team scored a goal in the 90th minute of the first match, it would remain intact in the final data matrix. However, the same goal scored during the second match would have obtained a registration time in minute 180. In this way, it was possible to obtain an inter and intra championship temporal vision. This procedure of preparation of the data for the analyzes, was applied in an identical way to both teams.

\section{Data analysis}

For the analysis, the Theme technique was used (Magnusson, 2005). Its application is common in a variety of social interaction contexts, but it is in the field of motor interaction (Parlebas, 2001) with recent examples in basketball (Pic, 2017) or football (Cavalera et al., 2015; Amatria et al., 2017) among others, where similarities with the presented analyzes can be seen. According to Magnusson (2000, p. 94), «that is, if $A$ is an earlier and $B$ a later component of the same recurring temporal pattern then after an occurrence of $\mathrm{A}$ at $\mathrm{t}$, there is an interval $[\mathrm{t}+\mathrm{d} 1, \mathrm{t}+\mathrm{d} 2](\mathrm{d} 2 \geq \mathrm{d} 1 \geq \mathrm{d} 0)$ that tends to contain at least one occurrence of $\mathrm{B}$ more often than would be expected by chance». Theme is an analysis technique that contemplates the temporal dimension of the registers realized. This way, Theme responds to the what and when of the records, inextricably. In order to perform the search for T-patterns, we started with restrictions of significance levels $(p<.005)$, determining the minimum number for T-patterns selection in 3.

\section{Results}

Table 2 shows the temporal distribution of carried out events, using 
the criteria included in the registration system in both championships. It was shown that, while in the Premier League 2457 T-patterns were found, 681 of these were carried out by different T-patterns, and in La Liga 6228 T-patterns were found, 1830 of which with different Tpatterns. The two lower images in table 2 verified the existence of similarities between La Liga and the Premier League in relation to the emergence of T-patterns.

Table 2.

On the left of the image, the most complex event time plot and T-pattern (below) found in out of temporal patterns, while blue events belong to T-patten.

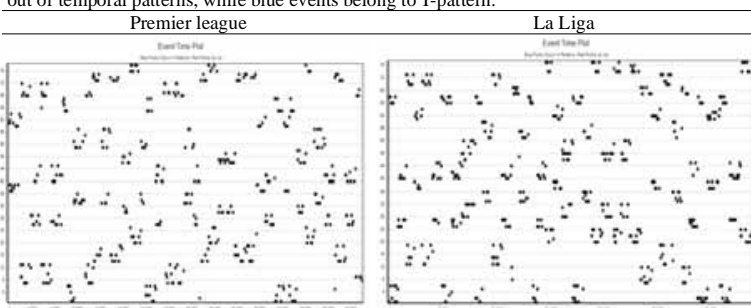
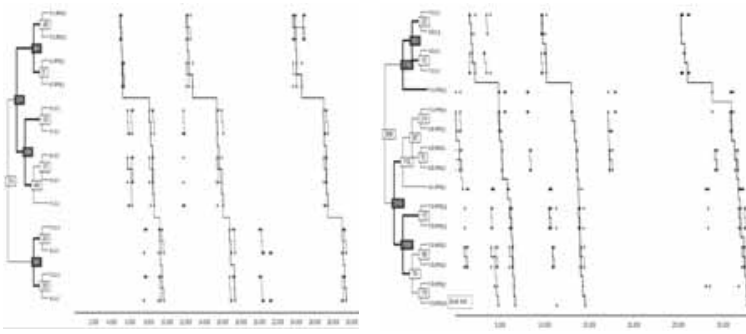

In Table 3, both the total number of T-patterns found (Occs) in both leagues, and the number of different T-patterns (Diff) were detected based on the quality of the adversaries. The greatest number of Tpatterns corresponded to the Spanish League, when Barcelona F.C. played at home, with 454, while for Leicester F.C. in the premier in the same local condition 68 were found. These differences were also evident when checking the different T-patterns, since Leicester F.C. obtained 20 for the 138 T-patterns of Barcelona F.C.

Table 3.

T-patterns based on number of occurrences (PattOccs) and number of different patterns (PattDiff) taking into account quality (Q), home advantage (HA) in La Liga and the Premier League. $\frac{\text { taking into account quality (Q), home advantage (HA) in La Liga and the Premier League. }}{\text { Premier League (Leicester F.C) }}$ Premier League (Leicester F.C) $\quad$ La Liga(Barcelona F.C.)

\begin{tabular}{ccccccccc} 
& \multicolumn{2}{c}{ home } & \multicolumn{2}{c}{ away } & \multicolumn{2}{c}{ home } & \multicolumn{2}{c}{ away } \\
\cline { 2 - 9 } & Patt Occs & Patt Diff & Patt Occs & Patt Diff & Patt Occs & Patt Diff & Patt Occs & Pat Diff \\
\hline Q1 & 0 & 0 & 82 & 25 & 0 & 0 & 0 & 0 \\
Q2 & 56 & 16 & 0 & 0 & 311 & 96 & 0 & 0 \\
Q3 & 0 & 0 & 27 & 9 & 0 & 0 & 263 & 69 \\
Q4 & 12 & 4 & 0 & 0 & 143 & 43 & 182 & 56 \\
\hline total & 68 & 20 & 109 & 34 & 454 & 139 & 445 & 125 \\
\hline
\end{tabular}

Also as visitors, there were differences favorable to the Spanish league regarding the Premier League. In the Premier League, $109 \mathrm{~T}$ patterns were shown, whereas in the Spanish League these proportions were obtained four times with 445. T-patterns were also different, with 34 for the Premier League and 125 for the Spanish League.An appreciation that should not be overlooked is related to an intra-championship comparison. In the Premier League, more T-patterns were obtained, different when playing under the condition of visitor than when doing it as local (68 local T-patterns - 109 away T-patterns = 41 T-patterns, also found in relation to different T-patterns with $14 \mathrm{~T}$-patterns favorable to visitor. However, in the Spanish championship, there were more T-patterns and different favorable T-patterns through the local condition, i.e. in Barcelona F.C. there were greater regularities when playing as a local than when doing it as a visitor. The highest number of T-patterns were identified in the Premier League when Leicester F.C. played against high quality teams Q1 with the away condition, while in La Liga they were found when Barcelona F.C. played as a home team against quality teams Q2.

By including location and teams quality (Table 3), differences between La Liga and the Premier League were verified. In the Premier League $56 \mathrm{t}$-patterns and 16 different T-patterns were found, playing at home against quality teams between 6th and 10th classified Q2, but these values were reduced when playing against teams between 16th and 20th Q4 with 12 T-patterns and 4 different T-patterns. T-patterns were not found when examining the quality Q1 or Q3 as locals instead, in the same championship as visitors, no T-patterns were found through qualities Q2 and Q3. The T-patterns were found playing against quality teams between the 1st and 5th ranked Q1 and Q3, i.e. against teams between 11th and 15th.

Table 4.

Dendogram composed by the most complex T-patterns identified in the Premier League (Leicester F.C.).
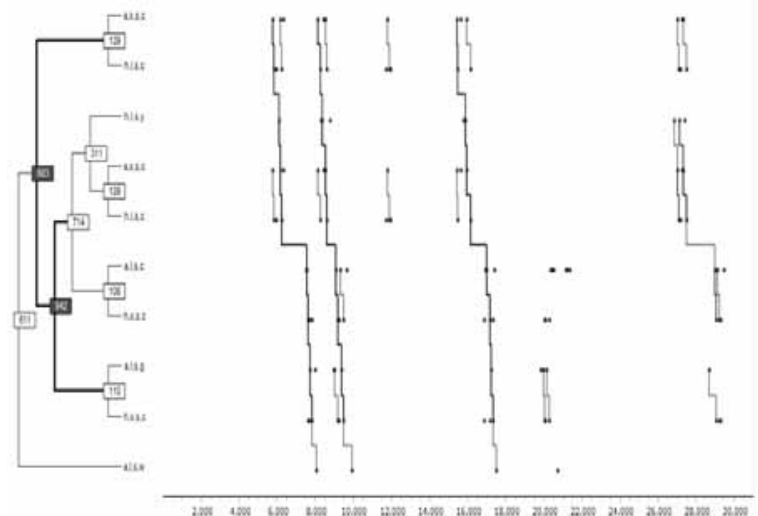

Some similarities between the championships were found when checking Q2 and Q3. In the Spanish championship, there were Tpatterns in Q2 as local, and in Q3 as visitors. This did not distinguish La Liga and the Premier League, but offered a meeting point between the development of both championships. Also, no T-patterns were found when playing as local and playing against the best teams Q1 in the English or Spanish championships, although partially. In the Premier League T-patterns were found under the away role against Q1, which did not happen in the Spanish championship. This was a remarkable difference, as it was evident that Barcelona F.C. showed T-patterns whenever they played against weak opponents Q4, i.e. under local and visitor conditions. However, they did not show T-patterns when playing against high-quality teams Q1 under the same previous conditions of local and visitor

Table 4 and table 5 showed the ordering of the registrations that emerged in both championships by conducting a victory search, to determine in what conditions the success of the champion team with the highest temporal recurrence occurred. Table 3 showed that in the Premier League many T-patterns (82 pattoccs) were found when Leicester F.C. played away from his stadium against high-quality rivals Q1 while in La Liga, playing Barcelona F.C. as local against lower quality teams Q2, there were more T-patterns (311 pattoccs). It should be remembered that, while variables such as quality remained unchanged at least during a match, variables such as goals or cards were changing events for each match instead.

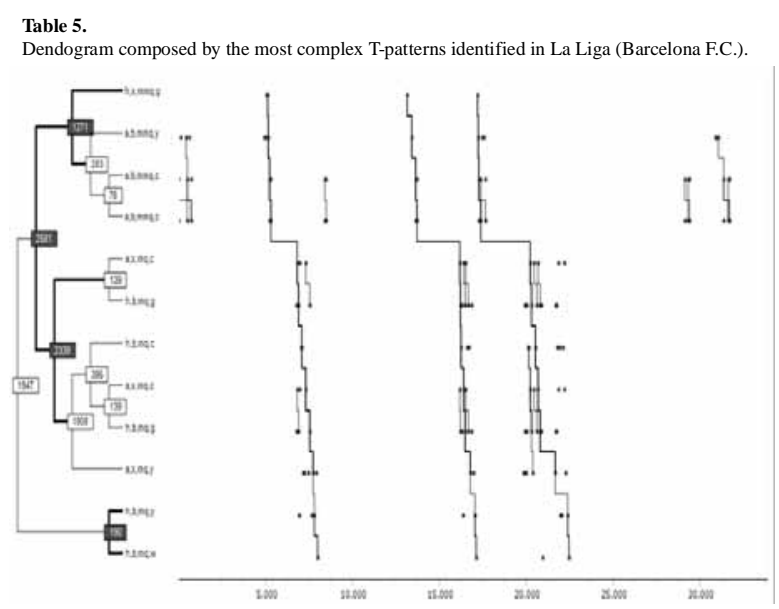


It was found that high-quality rivals (x) teams of Leicester F.C. made temporary structured changes (c) reflecting the first set of dendogram events $(\mathrm{a}, \mathrm{X}, \mathrm{s}, \mathrm{c})$ in table 4 . A relationship with the response offered by Leicester FC, by activating the making of changes when playing as local $(\mathrm{h}, \mathrm{l}, \mathrm{s}, \mathrm{c})$ was also found. The referees showed yellow cards to Leicester F.C. playing as a local (h, l, s, and), which implied that, on the one hand, the visiting rivals of leicester F.C. made changes (a,X,s,c) and, on the other hand, Leicester F.C. responded equally as local (h, l, s, c). Changes made by Leicester F.C. as a visitor (a,l,s,c) were reproduced by the rivals but as local (h,X,S,c). However, this differed when Leicester F.C. was a visitor and scored a goal $(\mathrm{a}, \mathrm{l}, \mathrm{s}, \mathrm{g})$, to which the rival teams made changes (c) being local (h,X,s,c).

In the case of table 5, in La Liga (Barcelona F.C.) when mediumquality rivals Q3 scored a goal at home (h,X,mmq,g) Barcelona F.C., playing away, obtained yellow cards (a,b,mmq,y), activating the making of changes (a,b,mmq,c) that was repeated again. On the other hand, it was also found that when visiting rivals Q2 of Barcelona F.C. made changes (a,X,mq,c) Barcelona managed to score against teams with the same quality.

As it happened with Leicester F.C., local changes (h,b,mq,c) were followed by more changes made by the opponent $(\mathrm{a}, \mathrm{x}, \mathrm{mq}, \mathrm{c})$ and the achievement of goals by Barcelona F.C. The last three behavior groups activated the rival of Barcelona F.C. getting yellow cards (a,X,mq,y). Finally, an intra-team T-pattern showed that the yellow cards against Barcelona F.C. activated the appearance of the local victory of Barcelona F.C. against teams with the same quality Q2.

\section{Discussion and Conclusions}

Among the findings of the present study, the identification of a hidden order in the identification of events in two of the best regular league football championships was the main reason for this study. We used a previously employed analysis technique (Magnusson, 2005), using approaches from an observational methodology (Anguera, \& Hernández-Mendo, 2014, Anguera, \& Hernández-Mendo, 2016) and fencing studies (Tarragó, Iglesias, Michavila, Chaverri, Ruiz-Sanchis, \& Anguera, 2015) or specific for soccer (Borrie et al., 2002) among others.

The number of goals scored by the teams (Armatas, Yiannakos, \& Sileloglou, 2007) according to location could enrich the discussion of the results. While Barcelona F.C. scored an average of 3.56 goals per game at home, the opposing teams scored only 0.74 goals against Barcelona F.C. at home. The goal could trigger decisions by coaches (Del Corral, Pestana-Barros, \& Prieto-Rodriguez, 2008) such as making substitutions (Myers, 2012) to give players rest. This data changed in Leicester F.C. with 1.84 goals in favor at home and 0.95 goals per game scored by rivals at the English champion's home. When comparing both teams as visitors, Barcelona F.C. scored an average of 2.37 goals per game away of their stadium but the rivals got as local 0.79 against visiting Barcelona F.C. On the side of Leicester F.C., values of 1.74 goals were reached as local, while they received 0.95 goals as a visitor. Although information on the effectiveness (Lapresa et al., 2015) of the teams was not offered, the goal could hide a lot of information to characterize both regular league championships. In the UEFAChampions League, it was shown that losing leads led coaches to make offensive changes (Rey, LagoBallesteros, \& Padrón-Cabo, 2015).

Barcelona F.C. reached almost seven times more T-patterns than the English team when participating playing as local, but also as a visitor, although to a lesser extent. That is, regularities measured in $\mathrm{T}$ patterns were found in Barcelona F.C. regardless of location. In contrast, Leicester F.C. reached more T-patterns as a visitor than as local, while Barcelona F.C. almost did not offer differences between playing as local or as a visitor. Different arguments could support or argue these results, so it would be appropriate to contextualize both championships through some descriptive data such as the final distribution in the ranking, percentages of goals scored and received based on the location or number of victories.

In La Liga, Barcelona F.C. was proclaimed champion with 91 points, followed by Real Madrid with 90 points and Atlético de Madrid with 88 points. In the Premier League, Leicester F.C. finished the championship with 81 points, while Arsenal F.C. and Tottenham F.C., got 71 and 70 points, respectively. When comparing both championships (Sarmento et al., 2013), in the top three, there was more competitiveness in the Spanish championship than in the English one. The 10 points difference between Leicester F.C. and the second classified helped to reinforce this previous idea, as would also be worth considering that there was only a 3 points difference between the first and third classified in the Spanish championship. It would be relevant to note the differences found in both championships between the first classified and the fifth, which were 29 points in the Spanish championship and 15 points in the English on. In the same order, from the first classified to the tenth place there were 46 points and 31 points differences respectively, for Barcelona F.C. and Leicester F.C. From the first to the fifteenth position it was 49 and 31 points, while in the twentieth position there were the biggest differences with 59 points in the Spanish League and 64 in the Premier League.

It is likely that equality in quality among teams warned of the great difficulty in taking the initiative in the game (Lago-Peñas, \& Dellal, 2010) or imposing a strategic plan, with its associated events in the form of goals, etc. This could be one reason why T-patterns were not found in Barcelona F.C. against high-quality teams Q1. This fact was confirmed, although only partly in the English team, since the T-patterns were found when playing as visitor against high-quality teams Q1. Leicester F.C. could act with a more defined plan for the HAphenomenon (Pollard, 2006). Although, in the past, greater statistical significance was found around HA (Corneya, \& Carron, 1992), the effects have now slowed. In fact, inverse HA was identified in hockey (Wright, \& Voger, 1995) and golf (Wright \& Jackson, 1991).The fact of having found higher HA in the Spanish (Saavedra, Gutiérrez, Fernández, \& Sa, 2015) championship than in the English Premier League between 200612 (Pollard, \& Gómez, 2014) could explain some of the T-patterns found when Barcelona F.C. played as local.

Double-match football (Page, \& Page, 2007) also showed trends that pointed to a certain reverse HA in the semi-finals of the Champions League (Pic, \& Castellano, 2016) or Copa del Rey (Pic, \& Castellano, 2017). Thus, at least in this sense, it does not seem unusual to identify temporary regularities when playing as a visitor in English and Spanish football. It would be a mistake to identify the recurrence of events with sports performance but, in the case of Barcelona F.C., the identification of T-patterns as a visitor emerged exclusively against lower-quality teams Q3 and Q4. The quality of the rival certainly facilitated this identification of T-patterns and, on the other hand, teams with a defined game model could show it with less difficulty against weak opponents.

Among the limitations and future applications, the increase in the number of variables included for the analysis could be one of them. On the other hand, control of the quality of the teams (Leicester F.C. and Barcelona F.C.) was another reason, since it was decided not to control the quality of the teams representing each championship because they won the championship, and perhaps including the quality of these teams would have made it difficult to find T-patterns. In any case, both teams remained in their respective ranking in Q1, except for a match in which the Leicester F.C. descended. Although football performance still requires further advancement in data analysis, inclusion of other dimensions could be a priority.

From the identification of temporal regularities using a selection of variables, applications for high performance could be derived. Each championship, through its respective champion team, responded with the activation of certain T-patterns (Magnusson, 1996; Jonsson et al., 2010), which can be used by coaches to plan long-term seasons, but also condition training. Temporary regularity is a rather unknown concept, but it can provide a different and enriching vision that makes it easier for coaches to fulfill their pretensions to optimize complex collective performance.

To conclude, these and other singularities from both soccer championships, were identified by using Theme as a technique for data 
reduction. Thus, to overcome a random glance is the beginning of a detection of indicators (Hughes, \& Bartlett, 2002) that help to concretize formulas of specificity in performance. This was the biggest task, forging a tangible image of the success in high performance football in two of the best known football championships.

\section{Acknowledgments}

Two Spanish government projects (Ministerio de Economía y Competitividad): 1) La actividad física y el deporte como potenciadores del estilo de vida saludable: Evaluación del comportamiento deportivo desde metodologías no intrusivas [Grant number DEP2015-66069-P, MINECO/FEDER, UE]; 2) Avances metodológicos y tecnológicos en el estudio observacional del comportamiento deportivo [PSI2015-71947REDP, MINECO/ FEDER, UE].

\section{References}

Almeida, C. H., Ferreira, A. P., \& Volossovitch, A. (2014). Effects of match location, match status and quality of opposition on regaining possession in UEFAChampions League. Journal of human kinetics, 41(1), 203-214. doi:10.2478/hukin-2014-0048

Álvarez, A., Ortega, E., Gómez, M.A., \& Salado, J. (2009). Estudio de los indicadores de rendimiento defensivos en baloncesto de alto rendimiento. Cuadernos de Psicología del Deporte, 9, 71.

Amatria, M., Lapresa, D., Arana, J., Anguera, M. T., \& Jonsson, G. K. (2017). Detection and Selection of Behavioral Patterns Using Theme: AConcrete Example in Grassroots Soccer. Sports, 5(1), 20.

Anguera, M. T., \& Hernández-Mendo, A. (2016). Avances en estudios observacionales de Ciencias del Deporte desde los mixed methods. Cuadernos de Psicología del Deporte, 16(1), 17-30.

Anguera., M. T., \& Hernández-Mendo, A. (2014). Metodología observacional y psicología del deporte: Estado de la cuestión. Revista de Psicología del Deporte, 23(1), 103-109.

Armatas, V., Yiannakos, A., \& Sileloglou, P. (2007). Relationship betweeen time and goal scoring in soccer games: analysis of three World Cups. International Journal of Performance Analysis in Sport, 7(2), 48-58.

Balagué, N., Torrents, C., Hristovski, R., \& Kelso, J. A. (2017). Sport science integration: An evolutionary synthesis. European Journal of Sport Science, 17(1), 51-62.

Barnes, C., Archer, D., Hogg, B., Bush, M., \& Bradley, P. S. (2014). The evolution of physical and technical performance parameters in the English premier league. International Journal of Sports Medicine, 35(13), 1095-1100. doi:10.1055/s-00000028

Borrie, A., Jonsson, G. K., \& Magnusson, M. S. (2002). Temporal pattern analysis and its applicability in sport: An explanation and exemplar data. Journal of Sports Sciences, 20(10), 845-852.

Boyko, R. H., Boyko, A. R., \& Boyko, M. G. (2007). Referee bias contributes to home advantage in English Premiership football. Journal of Sports Sciences, 25(11), 1185-1194

Bradley, P. S., Sheldon, W., Wooster, B., Olsen, P., Boanas, P., \& Krustrup, P. (2009). High intensity running in English FA Premier League soccer matches. Journal of Sports Sciences, 27(2), 159-168.

Bray, S. R., Law, J., \& Foyle, J. (2003). Team quality and game location effects in English professional soccer. Journal of Sport Behavior, 26(4), 319-33.

Buraimo, B., Forrest, D., \& Simmons, R. (2010). The 12th man?: refereeing bias in English and German soccer. Journal of the Royal Statistical Society: Series A(Statistics in Society), 173(2), 431-449.

Buraimo, B., Simmons, R., \& Maciaszczyk, M. (2012). Favoritism and referee bias in European soccer: Evidence from the Spanish League and the UEFAChampions League. Contemporary Economic Policy, 30(3), 329-343.

Caballero, P., García-Rubio, J., \& Ibáñez, S. (2017). Influence of situational variables on the U'18 soccer performance analysis. Retos - Nuevas Tendencias en Educación Física, Deporte y Recrea- ción, 32, 224-227.

Camerino, O., Chaverri, J., Anguera, M. T., \& Jonsson, G. K. (2012). Dynamics of the game in soccer: Detection of T-patterns. European Journal of Sport Science, 12(3), 216-224.

Castellano, J., \& Casamichana, D. (2016). Mismos jugadores con diferentes entrenadores, $\dot{c}$ se puede jugar de manera diferente para optimizar el rendimiento en el fútbol profesional?. SPORT TKRevista EuroAmericana de Ciencias del Deporte, 5(2), 133-140.

Castellano, J., Blanco-Villaseñor,A., \& Alvarez, D. (2011). Contextual variables and time-motion analysis in soccer. International journal of sports medicine, 32(6), 415-421.

Cavalera, C., Diana, B., Elia, M., Jonsson, G K., Zurloni, V., \& Anguera, M. T. (2015). T-pattern analysis in soccer games: Relationship between time and attack actions. Cuadernos de psicologia del deporte, 15(1), 41-50.

Clarke, S. R., \& Norman, J. M. (1995). Home advantage of individual clubs in English soccer. The Statistician, 44(4), 509-521. http:// dx.doi.org/10.2307/2348899

Courneya, K. S. \& Carron, A. V. (1992). The home advantage in sport competitions: A literature review. Journal of Sport and Exercise Psychology, 14(1), 13-27.

Courneya, K. S., \& Cheiadurai, P. (1991). A Moid of Performance Measures in Baseball. Journal of Sport and Exercise Psychology, 13(1), 16-25.

Del Corral, J., Pestana-Barros, C., \& Prieto-Rodriguez, J. (2008). The determinants of soccer player substitutions: A survival analysis of the Spanish soccer league. Journal of Sports Economics, 9(2), 160 172.

Dellal,A., Chamari, K., Wong, D. P., Ahmaidi, S., Keller, D., Barros, R., ... \& Carling, C. (2011). Comparison of physical and technical performance in European soccer match-play: FA premier league and La Liga. European Journal of Sport Science, 11(1), 51-59. doi:10.1080/17461391.2010.481334.

Eugster, M. J., Gertheiss, J., \& Kaiser, S. (2010). Having the second leg at home - advantage in the UEFA champions league knockout phase?. Journal of Quantitative Analysis in Sports, 7(1), 1-9.

Fernández-Rio, J., \& Méndez-Giménez, A. (2016). El aprendizaje cooperativo: Modelo pedagógico para Educación Física. Retos - Nuevas Tendencias en Educación Física, Deporte y Recreación, 29, 201-206.

García, J., Sáez, J., Ibáñez, S. J., Parejo, I., \& Cañadas, M. (2009). Home Advantage in ACB league 2007-2008. Revista Psicología del Deporte, 18 (suppl), 331-335.

Gayton, W. F., \& Langevin, G. (1992). Home advantage: Does it exist in individual sports. Perceptual and Motor Skills, 74(3), 706-706.

Gómez, M. A., de la Serna, A., Lupo, C., \& Sampaio, J. E. (2016). Effects of game location, quality of opposition, and starting quarter score in the outcome of elite water polo quarters, The Journal of Strength \& Conditioning Research, 30(4), 1014-1020.

Gómez, M. A., Gómez-López, M., Lago, C., \& Sampaio, J. (2012). Effects of game location and final outcome on game-related statistics in each zone of the pitch in professional football. European Journal of Sport Science, 12(5), 393-398.

Gómez, M. A., Lago, C., \& Pollard, R. (2013). Situational variables. Routledge Handbook of Performance Analysis in Sport. London and New York: Routledge.

Gómez, M.A., Lago-Peñas, C., Viaño, J., \& González-García, I. (2014). Effects of game location, team quality and final outcome on gamerelated statistics in professional handball close games. Kineziologija, 46(2), 249-257.

Gómez, M. A., Lorenzo, A., Ortega, E., \& Olmedilla, A. (2007). Diferencias de los indicadores de rendimiento en baloncesto femenino entre ganadores y perdedores en función de jugar como local o como visitante. Revista de psicología del deporte, 16(1).

Gómez, M. A., Pollard, R., \& Luis-Pascual, J. C. (2011). Comparison of the home advantage in nine different Professional team sports in Spain. Perceptual and Motor Skills, 113(1), 150-156. 
Gruic, I., Vuleta, D., \& Milanovic, D. (2006). Performance indicators of teams at the 2003 Men's World Handball Championship in Portugal. Kinesiology, 38(2), 164-173.

Hughes, M. D., \& Bartlett, R. M. (2002). The use of performance indicators in performance analysis. Journal of sports sciences, 20(10), 739-754.

Jamieson, J. P. (2010). Home field advantage in athletics: a metaanalysis. Journal of Applied Social Psychology, 40, 1819-1848. http://dx.doi.org/10.1111/j.1559-1816.2010.00641.x

Jonsson, G. K., Anguera, M.T., Sánchez-Algarra, P., Olivera, C., Campanico, J., Castañer, M., .... \& Magnusson, M. (2010). Application of T-pattern detection and analysis in sports research. Open Sports Sciences Journal, 3, 95-104.

Krumer, A. (2017). On winning probabilities, weight categories, and home advantage in professional judo. Journal of Sports Economics, 18(1), 77-96.

Lago, C. (2009). The influence of match location, quality of opposition, and match status on possession strategies in professional Association football. Journal of Sports Sciences, 27(13), 14631469.

Lago-Peñas, C., \& Dellal, A. (2010). Ball possession strategies in elite soccer according to the evolution of the match-score: the influence of situational variables. Journal of Human Kinetics, 25, 93-100.

Lago-Peñas, C., \& Lago-Ballesteros, J. (2011). Game location and team quality effects on performance profiles in professional soccer. Journal of Sports Science and Medicine, 10(3), 465-471.

Lapresa, D., Camerino, O., Cabedo, J., Anguera, M. T., Jonsson, G. K., \& Arana, J. (2015). Degradación de T-patterns en estudios observacionales: Un estudio sobre la eficacia en el ataque de fútbol sala. Cuadernos de Psicología del Deporte, 15(1), 71-82.

Liu, H., Yi, Q., Giménez, J. V., Gómez, M. A., \& Lago-Peñas, C. (2015). Performance profiles of football teams in the UEFA Champions League considering situational efficiency. International Journal of Performance Analysis in Sport, 15(1), 371-390.

Magnusson, M. S. (1996). Hidden real-time patterns in intra-and interindividual behavior: Description and detection. European Journal of Psychological Assessment, 12(2), 112-123.

Magnusson, M. S. (2000). Discovering hidden time patterns in behavior: T-patterns and their detection. Behavior Research Methods, Instruments \& Computers, 32(1), 93-110.

Magnusson, M. S. (2005). Understanding social interaction: Discovering hidden structure with model and algorithms. In L.Anolli, S. Duncan, M.S. Magnusson, \& G Riva (Eds.), The hidden structure of social interaction. From genomics to culture patterns. Amsterdam: IOS Press, 51-70.

Marcelino, R., Mesquita, I., Palao, J. M., \& Sampaio, J. (2009). Home Advantage in highlevel volleyball varies according to set number. Journal of Sport Science and Medicine, 8(3), 352-356.

Morley, B., \& Thomas, D. (2005). An investigation of home advantage and other factors affecting outcomes in English one-day cricket matches. Journal of sports sciences, 23(3), 261-268. http://dx.doi.org/ 10.1080/02640410410001730133

Myers, B. R. (2012). A proposed decision rule for the timing of soccer substitutions. Journal of Quantitative Analysis in Sports, 8(1), 124.

Page, L., \& Page, K. (2007). The second leg home advantage: Evidence from European football cup competitions. Journal of Sports Sciences, 25(14), 1547-1556. 37.

Parlebas, P. (2001). Juegos, deporte y sociedad. Léxico comentado de praxiología motriz. Barcelona: Paidotribo.

Pic, M. (2017). Detection of temporal structures in basketball. SPORT TK-Revista EuroAmericana de Ciencias del Deporte, 6(suppl), 199-206.

Pic, M., \& Castellano, J. (2016). Efecto de la localización del partido en eliminatorias de ida y vuelta de la UEFA Champions League. RICYDE. Revista internacional de ciencias del deporte, 44(12), 149-163. http://dx.doi.org/10.5232/ricyde2016.04405
Pic, M., \& Castellano, J. (2017). Influence of match location in the spanish Copa del Rey. Retos - Nuevas Tendencias en Educación Física, Deporte y Recreación, 31, 202-206.

Pollard, R. (1986). Home advantage in soccer: Aretrospective analysis. Journal of Sports Sciences, 4(3) 237-248. http://dx.doi.org/10.1080/ 02640418608732122

Pollard, R. (2002). Evidence of a reduced home advantage when a team moves to a new stadium. Journal of Sports Sciences, 20(12), 969973. http://dx.doi.org/10.1080/026404102321011724

Pollard, R. (2006). Worldwide regional variations in home advantage in association football. Journal of sports sciences, 24(3), 231-240.

Pollard, R., \& Gómez, M. A. (2012). Reassessment of home advantage in Spanish handball: comment on Gutiérrez et al (2012). Perceptual and Motor Skills, 115(3), 937-943. http://dx.doi.org/10.2466/ 06.05.PMS.115.6.937-943

Pollard, R., \& Gómez, M.A. (2014). Components of home advantage in 157 national soccer leagues worldwide. International Journal of Sport and Exercise Psychology, 12(3), 218-233. http://dx.doi.org/ 10.1080/1612197X.2014.888245

Pollard, R., \& Pollard, G (2005). Home advantage in soccer:Areview of its existence and causes. International Journal of Soccer and Science, $3(1), 28-38$

Rampinini, E., Impellizzeri, F., Castagna, C., Coutts, A., \& Wisløff, U. (2009). Technical performance during soccer matches of the Italian Serie A league: Effect of fatigue and competitive level. Journal of Science and Medicine in Sport, 12(1), 227-233. doi:10.1016/ j.jsams.2007.10.002.

Rey, E., Lago-Ballesteros, J., \& Padrón-Cabo, A. (2015). Timing and tactical analysis of player substitutions in the UEFA Champions League. International Journal of Performance Analysis in Sport, 15(3), 840-850

Saavedra, M., Gutiérrez, Ó., Fernández, J.J., \& Sa, P. (2015). Measuring Home Advantage In Spanish Football (1928-2011). Revista Internacional de Medicinay Ciencias de la Actividad Física yel Deporte, 15 (57), 181-194

Sarmento, H., Pereira,A., Matos, N., Campaniço, J., Anguera, M. T., \& Leitão, J. (2013). English Premier League, Spain's La Liga and Italy's Serie's A - What's Different? International Journal of Performance Analysis in Sport, 13(3), 773-789.

Tarragó, R., Iglesias, X., Michavila, J. J., Chaverri, D., Ruiz-Sanchis, L., \& Anguera, M. T. (2015). Analysis of patterns in bouts elite epee. Cuadernos de Psicología del Deporte, 15(1), 151-160.

Veroz, R., Yagüe, J. M., \& Tabernero, B. (2015). Incidencia de dos modelos de competición de fútbol sobre los valores socio-educativos en prebenjamines. Retos - Nuevas Tendencias en Educación Física Deporte y Recreación, 28, 84-89.

Wright, E. F., \& Jackson, W. (1991). The home-course disadvantage in golf championships: Further evidence for the undermining effect of supportive audiences on performance under pressure. Journal of Sport Behavior, 14(1), 51-60.

Wright, E. F., \& Voyer, D. (1995). Supporting audiences and performance under pressure: The home-ice disadvantage in hockey championships. Journal of Sport Behavior, 18(1), 21-28.

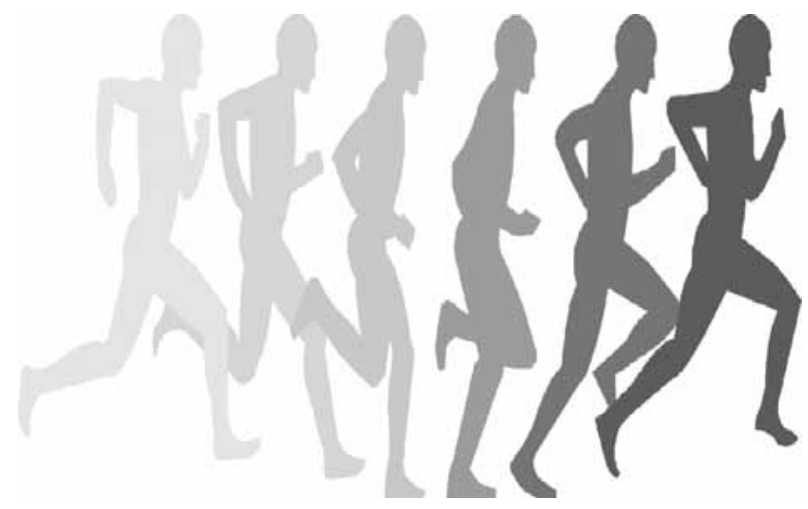

